\title{
Living Strategies of Dead Identities: Ideological and Psychological Motivation Behind the Expression and Transformation of Identity in the So-Called (Yugo)nostalgic Genre
}

\author{
Igor Gajin \\ The Academy of Arts Osijek \\ gajinigor@gmail.com
}

\section{DOI:10.5901/mjss.2014.v5n22p441}

\begin{abstract}
Yugonostalgia is a phenomenon that remains vital in the regional (pop) culture and mediasphere, although the Yugoslav state community and its cultural framework, as the source and foundation of the (re) constitutive identity recognition and formation, have broken apart a quarter century ago. Moreover, there is still small community introducing demselves as Yugoslavs and demanding recognition as official minority. Partly comparable with Eastern European Ostalgie as a characteristic manifestation of an understandable identity crisis in a transition period, perseverance and representations of Yugonostalgia reflect the processes of desire for identity and identification through dialogue or debate between the past, towards which Yugonostalgia is directed, and the current time, which through its position and strategy Yugonostalgia not only interprets, but also confirms. After being politically inappropriate in the nineties, and commercialized in the early 21st century, Yugonostalgia in Croatia turns into a social genre through recent publications, responding to effects of global recession and pressures of neoliberal capitalism. All these genre changes of Yugonostalgia signal its continuing ability to revitalize and adapt resources of the Yugoslav imaginarium to identity crises and needs of the post-Yugoslav today to the extent that it would be interesting to estimate/ forecast its effective expiry date.
\end{abstract}

Keywords: Yugonostalgia, Cultural Memory, Strategies, Transition, Identity

\section{Introduction}

According to the Croatian edition of Le Monde, several hundreds of citizens in Montenegro and Croatia have identified themselves as Yugoslavs for the purposes of census in 2011, and in Serbia the number rose up to 23 thousand people (Dérens, 2013). Admittedly, there were those who identified themselves as Eskimo or Jedi as well, so it may be that some of the "Yugoslavs" opted for such identification motivated by the same thing as "Eskimos" or "Jedi". It may have been an expression of subversive opposition to administrative classification and the repressive approach of the government apparatus, and opting against the reductive identity simplification, as well as resistance to the use of identity as a powerful cause of stratification (Bauman, 2009).

However, according to Dérens, there was even an initiative by the Yugoslavs that they be recognized as a minority.

Such a thing is still not within a conceiveable horizon of any ex-yu country's establishment, so the official replies are still categorically negative, followed by more or less reasoned explanations of how debatable the status of "Yugoslav identity" is in relation to the predominant, i.e. the official and nominal definition of the political and cultural identity. Danijela Majstorović (2013) defines the identity policies of the former Yugoslav republics as policies based on ethnic identity as the primary, or even sole criterion of essentialising the community. The ethnos or a nation, Majstorovic says, is regarded as the focus of identity and loyalty, and it represents the base of collective actions. Ethno-nationality, she says, is the "organising and legitimising principle in which there are characteristic practices of delegitimisation and relegitimisation, which is manifested through a specific discourse, and through the creation of 'us' and 'them'. Nationalism is instrumentalised through people's fears, and when people have chronic fears, they become extremely vulnerable to authority" (p. 160).

The signifier of "they" changes the signified or the content depending on the movements of daily politics, so "they" sometimes denotes the European Union, sometimes the anonymous globalization forces and the global capitalist elite, while sometimes it denotes the neighboring ex-yu republics (in Croatia's case, those republics are Serbia and Slovenia).

Although analysts and newspaper columnists argue that restoration of Yugoslavia is an illusory and historically superseded idea, an idea that best demonstrates its hopelessness through the collapse of its project, fear of Yugoslavia is periodically restored in the public discourse. For example, when the term Yugosphere was implemented in the discourse (even though 
the author of the term Tim Judah primarily had in mind the mapping of culturally close areas, and not a political renewal by means of "euphemism"), the voters were intimidated in the democratic election process through rumours of a certain party's "secret project" of Yugoslavia's restoration. The most recent example of the phobia was initiation of bilingualism in Vukovar, when one of the key slogans of resistance was: No to the Cyrillic is no to Yugoslavia.

In short, such an identity strategy is more often than not an explicit political project of tabooing the Other, an accentuated orientation towards identification as a process that is inevitably, at least in some aspect, a differentiation, which ultimately leads to exclusion of the Other (in fact, from the Croatian point of view, the Yugoslav project is equal to the Serbian hegemony and such a rhetoric greatly contributes to reinforcing the animosity towards the Serbian nationality).

On the other hand, the application and manifestations of the "Yugoslav identity" through the (pop) cultural and subcultural genres, as through the phenomenon of the so-called Yugonostalgia, have been present on the territory of former Yugoslavia for the past quarter century. The phenomenon appears in varying degrees and comes from different positions in dialogues and debates, so sometimes, paradoxically, it is even in accordance with the official discourse, so we can often witness the schizophrenic situation of political satanisation of Yugoslav cultural artifacts, at the same time seen as representatives of the Yugoslav idea and the products of media and mass culture (such as publishing of Tito's cookbook, stories of Tito's lifestyle, re-releases of the popular music albums from the Yugoslav period etc).

Therefore the aim of this study is to examine the discrepancy between the attitude towards Yugoslavianism and practices of Yugonostalgia as a form of political and cultural identity. The discrepancy will be examined with regards to the fact that the Yugoslav ideological, political and cultural history on one hand represents a trauma with association to a repressive, (semi)totalitarian and ideologised society (which has, among other things, ended in war bloodshed due to its nature, structure and the identity policy), and on the other hand it is an idealised space of nostalgia for "a better past". The following diachronic analysis of literary texts that, in nominal terms, belong to the so-called Yugonostalgic genre, will show that the representation of Yugonostalgia from one stage to another always serves to a current purpose, being in the role of a diagnostician, i.e. a critic of today, or as a propaganda opium of the dominant order, especially at a time when the postcommunist societies of former Yugoslav republics are reaching a phase of legitimising and disseminating of a seemingly disideologised capitalist logic of the system.

Yugonostalgia will prove to be a necessity for preserving cultural memory continuity, and will therefore gradually move from the areas of opposition and subversion and be promoted into a carnivalesque space of permissible excess, which contributes to stabilisation of social order. Ivan Lozica (2007) says: "The truth is that the Carnival is not true rebellion, the truth is that its (always current) social critique does not violate the dominant order directly. Its effects are more therapeutic and conciliatory, and it is a diversion that strives to strengthen cohesion in the community." (p. 203). In fact: "Power always uses art as an instrument, though it is not always clear how it manages to do so, and why. The answer may be provided through comparison with the carnival: is the artistic freedom not merely an illusory diversion, and in reality only a controlled outlet?" (p. 206).

Even though the Yugoslav cultural identity was absorbed and co-opted through genres of Yugonostalgia for reasons to follow, resistance to the "excess" demand that Yugoslavs be recognised as minorities suggests an evident complex with which the dominant order is clearly still struggling. Furthermore, such a demand- given the specificity of Yugoslav historyindicates that there is a process of testing the theoretical apparatus that deals with the phenomenon of identity in this particular instance. In point of fact, the "radical" seriousness of the aforementioned initiative with its expressed degree already reflects the characteristics of a project identity (Castells, 2002), and it represents a public stand, a public intervention of a group that seems to find the identity continuity an insufficient indicator of subject coherence and the coherence of the meaning of life (Kaufmann, 2006) through popular forms of Yugonostalgic culture and other idiosyncratic techniques which an individual uses to "unify a multitude of identification references associated with their personal history" (Kalanj, 2008, p. 60). To conclude that these initiators represent a typically rigid and non-negotiable identity (Bauman, 2009) or to diagnose that their idea is a classic reaction to a situation when "new orders start being considered mere vectors of destabilisation, which implies an even more unrelenting fixation" (Kaufmann, p. 48), goes in the favor of the idea that they should be (dis)qualified as "incorrigible" Yugonostalgics, as those who have dysfunctional ways of handling their identity attributes in relation to the current sociopolitical climate. In other words, it is as if their categorical identification with the culture of the former order were "an imaginary enclave in real social space" (Jameson, 2005), especially if we accept the statement "that the 'here and now' we still have an 'imprisonment identity theory"' (Luketić, 2013, p. 299). Even in the "field (of culture, AN) there is a prescribed level of mandatory unity and a degree of acceptable diversity in a community" because "a culture has the task of presenting the imaginary characteristics of a nation" (p. 275). 


\section{Method}

\section{Materials and procedure}

By using the findings of relevant identity theorists (Bauman, Castells, Kaufmann, etc.), the works of researchers of the phenomenon of nostalgia (Boym, Hutcheon, Velikonja, etc.) and the reactions of the media space, as well as the analysis of those elements of public discourse that relate to these issues, the study aims to detect the motives of a certain group's request for recognition of Yugoslavs as a minority. Through this phenomenon and in regards to the cultural context of the post-Yugoslav period, its ultimate aim is to bring new insights to the research of identity. In dealing with this form of "Yugonostalgia", the study applies the theories of memory, cultural memory and nostalgia strategies, finally offering an analysis of the inscribed policy of memory and nostalgia in the Croatian literary works that are, theme and genre-wise, nostalgic orientations based on the thesis that the nature of these texts and their mutual differences reveal strategies of identity, as well as the ideological motivation of the system's background. Particular attention will be drawn to the instances when the aforementioned discourses are accepted into cultural industry's momentum or into the discursive repertoire of political action. In the spirit of observations presented in the study Literature through recall (Škopljanac, 2013), a reading of literary examples demonstrates the mechanisms of memory, but also the blind spots of memory, whereby nostalgia is only one form of transforming the authentic past into a subjective experience, through which direction of the said subjectivity often provides an impulse in shape of a contemporary sociohistorical context.

\section{Results}

Even a diachronic cross-section reading of the Yugonostalgic genre in contemporary Croatian literature indicates that it is by no means a dogmatic or a conservative discourse, for if it were, as such it would be very short-lived or marginal. Instead, it is a dynamic genre that uses its spectrum of internal differences to show that it is capable of being current over and over by using the mechanisms of the memory industry, all the while detecting the neuralgic points of the social order, but also being prepared in certain circumstances to become an integral, even crucial part of narrative strategies in the process of ideologisation, which serves to constitute and maintain the order. In that, it is actually more important to grasp that the circulation, metamorphosis, adaptability and reactivity of the Yugonostalgic genre explains its vitality, durability, renewability and popularity for everyone who wonders how Yugonostalgia is possible and alive for a quarter century after its stem structure had collapsed. It is possible and vital not only because of the failure to master and dictate the cultural memory, but also because Yugonostalgia of the nineties is not the same as yesterday's or today's Yugonostalgia. It is alive, current and strong, as long as it skillfully recognises and translates relevant contemporary issues into the motives of its genre.

However, recognition of existence of the Yugoslav cultural identity through genres of Yugonostalgia and its political rejection based on refusal of the request that Yugoslavs get minority status, calls for questioning of Wodak's words:

if a nation is an imaginary community, and at the same time a mental construct, the imaginary complex of ideas that contain at least defining elements of collective unity and communion, borders and autonomy, then this picture is realistic to the extent to which someone is convinced in it, to the extent to which someone believes in it and emotionally identifies with the community. The question is how this imagined community comes to minds of those who believe in it is easy: a community is built and transmitted within a discourse (as cited in Majstorović, 2013).

The fact that new identity constructs, disseminated by discursive strategies and policies of the new elites, nevertheless failed to suppress the "emotional" power and "reality" of the Yugoslav imaginarium in some parts of the society, calls for an identity process re-evaluation in the place of the conflict.

\section{Findings of identity}

The request for official regulation of the Yugoslav identity as a minority group is (ir)rational for several reasons. It is rational in the understanding that identity is a socially necessary construct that creates conditions for effective action, and opting for "social anchors" of identity within an imaginary space of the seemingly irrevocably past, but which becomes the source of retrospective construct, active fiction (Velikonja, 2010), even a sentiment. It is also a strong and a logical place of entanglement of individual memory and the cultural memory, personal identity and the once collective identity, it is a starting 
point of establishing and maintaining identity continuity and coherence. If we have already defined identity work as "that which selects and processes elements which then become active strongholds" (Kaufmann, p. 70), the idea that Yugonostalgic foundation of identity in the vicinity of the aforementioned social climate could serve to such a purpose seems paradoxical, that is, irrational. Even though identity is a (self-)reflective process that destabilises the tendencies of collective identity towards a holistic and monolithic totality, there is a contrast to (self-)reflectivity of individual identity- a collective identity prone to processes of stereotyping and essentialisation is more likely to have its subjects conserved into a "mimetic nostalgia that is serious, dogmatic, unchanging and explicitly political and continuous" (Velikonja, p. 144), so such an identity strategy could be more or less accurately interpreted as "something backward, static (...), as a mere inertia or a reproduction of the past" (p. 135).

However, seeing identity as a process is in itself a paradoxical act: although the essentialist notion that identity is an entity has been completely disassembled, the fact is that- since an illusion and a narratively established fiction was formed through time- the identity has an eternally temporary status, so that "it is not a thing, but a linguistic description, a discursive structure that changes its meaning" (Kalanj, p. 46), that which "hardened (...) into a 'fact', a 'given' (Bauman, 2009, p. 23). So when Bauman tells us that identity "reveals itself only as a thing to be invented, not discovered" (p. 19), Kaufmann will comment on that paradox of an eternal process and a never completed identity, as well as the opposite tendencies directed towards the static, stiffening with the tendency of achieving a monolithic image of an "assumed I" so the subject could bear disparate meanings of an inconsistent reality, with a rhetorical question : "How can a movement (finding oneself) be induced by its opposite, a fixation (self-image)?" (Kaufmann, p. 80).

In the case of a seemingly futile functionalist foundation of identity as an experience of the Yugoslav culture and everyday life as a general framework that formed individual biographies, a psychological need for identity reliance as the animating principle of action which would form a meaning that should be attributed to actions, and in the "dual meaning of the word 'meaning': in the sense of significance, and in the sense of movement (Kaufmann, p. 128), the explanation lies in the effort to ensure continuity in biographical duration and to an even greater extent "self-esteem as a necessary energy in action" (Kaufmann, p. 59). Self-esteem should in this context be understood as a resource which the subject feeds on while "resisting (...) criminalisation of the past (...) thus keeping the continuity of identity from historical discontinuity. It preserves the past, which would have been stolen otherwise" (Velikonja, p. 165).

The seeming irrationality of such a strategy is therefore gradually losing the crucial prefix ir-. Even if construction of identity strongholds using the inventory of the past, cultural memory and personal histories is not controversial, it might seem controversial that in the said situation strongholds are not built of any given identity source from the historical and cultural repertoire, but of a specific, particular one. Such a thing happens not only because the individual is "being produced by the history he produces, (Kaufmann, p. 34), but also because he chooses the "troubling past" (Velikonja, p. 145) from the perspective of a legitimising identity which "instills the dominant social institutions to expand and rationalise its dominance in relation to social agents" (Castells, p. 18). So in this case we are facing a conflict between a normative and sociopolitical identity, as well as opposing the fact that "only those who have legitimate authority , the authority that stems from power, can impose their own definition on themselves and others" (Kalanj, p. 53). Heteroidentities, syncretic, dual or multiple identities are, of course, not a problematic category, but an interpreted, accepted and an implied occurrence of individual identity architecture. However, when it comes to an identity that is declaratively committed to the attribute Yugoslav, then this is worth of an observation by Rade Klanja who claims that the problem are dual identities whose "both reference halves are on the same level (...) and that there is no reason why a large number of identification references could not be unified into a single identity, except in those cases where a governing authority prevents it in the name of identity exclusivity" (Kalanj, p. 60).

\section{Findings of nostalgia}

Ivica Baković concludes that in the post-Yugoslav society Yugonostalgia transferred "from one constructed political scene (...) switched on (...) the other (popular) culture one", meaning to say that all the Yugonostalgic narratives come from the status of anti-narratives of a nation that (...) interfered with those ideological maneuvers through which the 'imaginary communities' gain an essentialist identity" (Babha, 2002, p. 168) and moved into a seemingly benign field of (pop)culture. Pop culture serves as an area that helps stabilise the order in terms of acceptable ways of dealing with the need for cultural identity continuity, but also co-opting the resistance identity, so much the better if it manages to turn nostalgia into mere retro, on the track of Linda Hutcheon's interpretation in "Irony, Nostalgia and the Postmodern" that describes postmodernism as entirely marked by nostalgia, or more precisely, if nostalgia fails to undergo the strategy of the postmodern narrative, "from media culture to art, which, adding its dose of spectacle and pop, changes the past into an 
exciting, scintillating, trivial story" (Velikonja, p. 130). In other words, the order replied to appearance of the "nostalgic culture" with the "culture of nostalgia", because according to Velikonja the nostalgic culture is nostalgia bottom-up; predisposition of the audience to feel such a sentiment, while the culture of nostalgia is "top-down", an offer of nostalgic content produced by the culture industry.

A message that clearly reads from the refusal to recognize the Yugoslavs as a minority, with simultaneous tolerance towards former Yugoslav cultural industry contents' consumation, as well as the occasional referencing of the (pop) cultural products to that "yesterday's world" is that (pop) culture is a ghetto blessed by ranking out of which nobody can step into what is politically sensitive and into the "narcissistic neuroses of a national discourse" (Babha, p. 169).

Specifically, the real political charge and the ideological argument comes not from the invoking of the concept of selfmanaging socialism and titoism in the "post-communist neo-communism", or in the attempt of restoring the previous regime in its political totality, as a better option than the current social order, but in the fact that Yugonostalgia is a reaction to today's problems. Therefore it can be said that through nostalgic narratives the weak points of the current order and the cracks in its ideological discourse are shown.

Indeed, such a dislocated or transcendent commenting of unsatisfactory present from a perspective of a utopian, nostalgised, and later fictionalised history "which never was", has been interpreted in detail, deconstructed, dissasembeled, and even indicated that there are some constituent defects of such a strategy, in form of discrediting arguments which cause termination of every dialogue and respect for the position it comes from. When summarised, those points are reduced to the complaint of escapism, passivity and submission to simulacrum, and most of all to the seemingly active struggle with the current problems from a hypocritically comfortable standpoint. However, Linda Hutcheon will say "never underestimate the power of nostalgia", Velikonja writes that nostalgia "can also be a strong social, cultural and political force with practical effects in its environment" (p. 32), while Jameson briefly and clearly summarises that nostalgia is always "for the present" (Jameson, 1991, p. 279). Jameson tells us that viewing nostalgia in terms of diachronic comparison "then and now" is a distorted perspective, since nostalgia is more relevant as a critical and commentator statement, reaction, i.e. the result of a current crisis in the relations between synchronic elements (Jameson, 2005). Although nostalgia brings the image of a "better past", that image is installed through the criterion of present. The past is then "articulated in the present, it is nothing but a cultural form of the present" (Buden, 2013, p. 21).

To sum up all possible objections to this genre as possibly escapist and fueling sweet sadness without an object, a quote by Charles Maier can be used: "Nostalgia is to memory what kitsch is to art" (Boym, 2001, XIV). Nontheless, a change in the focus interests of the Yugonostalgia genre, which uses Yugonostalgia as by no means random denominator and a remarkably chosen place of polemics, show that works of the Yugonostalgia genre are not necessarily a fossilization and the continuation of the past. Rather, they are a bi-directional active fiction: towards the past which is being retold or invented as a reductive and selective image that is, with its editing, not correspondent to the historical truth, but is distorted by desire, and equally towards the unsatisfactory present, criticising with the language of nostalgia the missing values of today, and a generally "less valuable present" (Velikonja), as well as the engineering of the identity. In support of this, Connerton says: "Our present world is experienced within a context causally associated with past events and things, and we therefore resource to them when we are unable to comprehend the present. And we will perceive out present differently depending on the different past times with which we can connect the present $(2004$, p. 6).

\section{Findings of background in yugonostalgic literature}

In the "brief" history of the Yugonostalgic genre in Croatian literature, the first major impact in terms of controversy and polemic was caused by a collection of essays The Culture of Lies by Dubravka Ugrešić, a work monumental for its longterm effects. Although it was primarily condemned in the former political climate for its critical view on the so-called tuđmanism, i.e. the ideology practices of contemporary nationalist discourse, in which it indicated the similarity between laws of the nationalist discourse and the socialist ideology, Ugrešić's book had a crucial role in supporting and legitimising the presence of Yugonostalgia in society. It demonstrated Yugonostalgia as a phenomenon that is not a project identity, or a "threatening" tendency towards Yugoslavia's reconstruction, but- since it is directed exclusively to the inventory of former everyday life and fetishising the artifacts of the Yugoslav cultural industry-only represents the need for identity continuity, for a relationship with oneself in relation to the proclaimed identity policy which has sought a radical with the former at every level, including the cultural and memory level.

People "remember (...) the history of triviality. And it is the culture of everyday life (and not a state or a political system), that is the source of Yugonostalgia ", says the author (2002, p. 175). 
Nevertheless, it was a time of a discourse that was "at the same time obsessively fixated on society's boundaries and the margins of the text, and unsure about those limits" (Bhabha, p. 163), frequently with such a normative and repressive discourse that "exaggerated ethnic identity (...) ceases to be a tool and turns into a straitjacket" (Devereux, as cited in Kalanj, p. 58), as was the case with reactionary development of odiousness towards vulgar practices and manifestations of empowering a new collective identity as Kaufmann's "increased singularity", "expanded self", or simply "personal enlargement". In such relations and tensions Ugrešić's book had identified and emancipated the culture of memory in relation to the dictatorship of oblivion, where we should highlight that "it is precisely the syntax of oblivion- or obligation to oblivion- which makes the problematic identification of a nation visible" (Bhabha, p. 180).

This campaign of identity resistance continued with a collection of essays How We Survived by Slavenka Drakulić, which is also a culturally and socially relevant realisation of mirroring and opposition to what Tanja Petrović (2011), using Marija Todorova's term lived communism, describes as "discrepancies between the prevailing 'official' attitudes towards socialist past experiences and the experienced socialism. The first are prescriptive (...). On the other hand, the experiences of socialism by the 'ordinary people' (...) offer a different view of the past and suggest a different hierarchy of values. Personal memories of socialism is very often not in accord with the dominant narratives (p. 427).

Klaus Roth (2012) adds that it was an undeniable fact that people were still integrated into the federal system of the time, where "socialist normality slowly and inconspicuously absorbed most people. Many eventually lost their awareness of the specific conditions of their normality, and this shared experience has created cultural intimacy, Roth points out (p. 33).

However, the key transfer of Yugonostalgia from a declaratively oppositional place to the Croatian literature mainstream was made by Goran Tribuson. He neutralised the explicit subversive nature of Yugonostalgia with his prolific sequence of autobiographical discourse and novelesque productions about a world and the protagnoists that come from a Yugoslav cultural milieu (Bošković, 2013). He had done this from a point of view of an infantile narrator (i.e. free from all the ideological compromising as an innocent object of indoctrination), as well as a humorous discourse which solved the problem of "discomfort" and "recommended consorship" of the Yugoslav past in individual memories. The trouble with those points that are generally the same in anyone's biography as a former shared framework of individual memory was overcome through the procedure of re-structuring it into anecdotes and thus diluting the delicate weight of even the most traumatic places in the Yugoslav history by the emancipating power of laughter.

The past is relived, only this time there are no consequences: not only are there no consequences for the jokes about Goli otok, Tito and other totems of Yugoslav ideology, but there are also no consequences in the current regime. Therefore, the uncertainty of dealing with the newly established "taboos" by the criterion of the dominant order moves to the space of tolerated transgression. Figuratively speaking, the Yugoslav decor in the background of Tribuson's narrative is presented as a photo album over which we laugh at our own "infatuation" with former hairstyles, clothes, trends, lifestyle, (ideologised) rhetoric in general, because we have outgrown them. In fact- as it appears in Tribuson's work- today we can be Yugonostalgic precisely because we are not Yugoslav anymore, and we have drifted away from that "surpassed" heritage.

Tribuson has become unparalleled in this maneuver, not deciding on Kundera's understanding of the role of laughter in society, but on Viewegh's interpretation of a more or less totalitarian period as simply "the wonderful years of lousy living". Thus, when we say that Tribuson has a "warm" humor, we actually mean that the key to his success in legitimising the Yugonostalgic narratives lies in the impression of meekness, rather than the cold official discourse.

By Yugonostalgia entering mainstream and by its de-politisation, i.e. by its acceptance as a legitimate and "unjeopardisable" memory, the ideologisation is not completed, as it starts being colonised by the capitalist ideology. After it was recognised as a market, based on previous success with Yugonostalgic themes, Yugonostalgia will wholeheartedly harness this industry of memories and start a cycle of exploitation of its imagery. One of the initial works that were turned into a consumerist fruitful resource was a multimedia package Happy child by Igor Mirković, supposedly a documentary product on a "renaissance" period of urban culture and a quasi-counterbalance to the revival of turbo-folk, but at the same time it is, and perhaps above all, a representative example of mercandising. Not only does it use the fact that "youth is the golden age of identity creation" (Kaufmann, p. 170) and that the time was a pinnacle of achievement for a significant series of generations, achievement that Bauman interprets with words "We need links, and we need such links in which we mean something, in which we define ourselves" (2009, p. 58), but also it attempts to "evoke nostalgia in consumers for what they have not lost in the first place" (Boym, 2001, p. 38).

It should be noted that Happy child deals with the 80 s, a period Ildiko Erdei (2012) refers to as the vestibule of transition. This is due to intensifying of the consumer culture among the citizens which led to the collapsing socialist system not being able to meet and satisfy the citizens' needs, she claims, but her thesis that the mythologised and mystified 80s were a 
culmination of the "childhood policy" that former Yugoslavia conducted seems even more important. Its goal was to satisfy the needs of a child through material things as well (through toys and other items that feed a child's consumerism) and thus it indirectly ideologised. So many today, in their mature age, remember the candy made in socialist factories with Proustian nostalgia, the candy named after partisan heroes or the key words of "socialist revolution". (p. 73-96).

A perfidious flair of commercial nostalgia is most obviously represented by Ante Tomić's novel "Nothing Can Surprise Us" and the further exploitation of the hit through film adaptation that turned into a regional hit Karaula, directed by Rajko Grlić. It is a product with such conscious commercialism that the development, especially of the film version of the project, targeted the market of all former Yugoslav republics from the very beginning. The novel was published in 2003, when narration and indirect popularisation of The Yugoslav People's Army truly no longer presented a taboo, nor could any thematic commitment mean a subversive or even treacherous glorification of the "hostile forces". Be that as it may, Tomić and Grlić had recognised the potential demand in the market for "untold stories" in the void of an established regime of "silence" towards this aspect of most biographies, that is, due to the lack of publicly articulated experience of compulsory military service in the subsequently defamed YPA. In it, a multitude of individual stories mirrored and verified itself through the renewed common reference framework, the collective experience, especially since the genre of military stories in YPA still is alive in oral culture.

Petrovic succintly explicates that which the authors have recognised as profitable: the potential of military stories to represent individual and collective narratives at the same time and still connect people despite the ethnic differences. The author recognises the right place, the focal point of constituting identity and constructing oneself in this narrative: past every ideological and political perspective, it is a source of representation of masculinity which "should be understood as a memory practice that plays an important role in reproduction of certain types of masculinity" (2011, p. 425-429).

The Yugonostalgic genre is still not exhaused, even in the second decade of the 21st century. Its popularity is not ongoing because the repertoire of the ex-Yugoslav mythemes and emotional symbols in inexhaustible, but because it is a vital genre that rotationally adjusts to the current movements in the market and keeps giving new meaning to the repertoire of the Yugoslav imagery depending on the needs of the moment. Since the "forbidden fruit" of Ugrešićs Culture of Lies over the popular marketing of Yugoslav imagery thanks to the emotional instability of the audience towards the retromania spectacle, Yugo-nostalgia has recently (2013) turned into a social genre through autobiographical prose of Ana Tajder, Titoland. The work quite accurately hits a nerve of a pauperised society that recognises the growing contrast between what it used to have, and a sense that it will never have it again. Here we are not talking about a realisation that we will never again be young, but about knowing that there is no way to enjoy the benefits and the standard of socialist working class again. There is no longer a delusion that the socialist utopia will be replaced in some time with the American dream, and everything will be better again if we only go through the transition, but it is about a growing awareness that the neoliberal capitalism will drain us and discard us on the pile of wasted resources as Baumann's "human waste". In the clear realisation that the future will surely not be better, the image of a better past once again becomes strongly attractive.

Hence Titoland, another individualised Yugo-biography, will be directed towards the current collective sensitivity and it will specifically put emphasis on the social note. Through the description of her upbringing, schooling in anonymising school coats, and through superficial panoramic scanning of the material decor of a socialist bourgeois family, the author will convey the message of a "truly accomplished equality' 'which then reigned, as well as the benefits that have stemmed from it: the lack of crime, lack of consumerist hell of a never satisfied desire, lack of exhaustion and wearing of a man through competition and market pressure, lack of status rivalry, absence of stress over the lack of superhuman performance in inhumanly tight deadlines...

The overall picture of Titoland is fairytale harmonious: everyone had enough of everything, sufficiently enough so that nobody would strive for aggressive and insatiable accumulation. Rather, there was a socially conscious solidarity that had made all the surplus labor selflessly pour into the benefit of the community, which resulted in infrastructure flourishing for all the desire comfort of citizens and the expansion of social services for all conceivable public needs and problems of society members. This is a clearly addressed comment on today's ' privatisation and commercialisation of what used to belong to the sphere of public and social goods. The peak of this idyllic idleness Ana Tajder underlines with the sentence: "those who were lazy, could remain being lazy".

From today's perspective, these images fall on fertile ground and offer themselves as support to existential uncertainties and anxieties of our identity today.

\section{Discussion}


Linda Hutcheon, referring to the dual nature of postmodernism as an ironic and nostalgic epoch, asserts that nostalgia is "transideological", which this paper calls into question. When we take into consideration that Hutcheon actually believes that nostalgia is a universal trait of the human nature which is used as a response to passing of time and that nostalgia is one of the dominant characteristics/ manifestations/ genres of the contemporary postmodern "structure of feeling", its "jargon of authenticity" sith regard to the belief in the postmodern exhaustion in relation to antiquated treatment of culture, it turns out that nostalgia is not only a general philosophic problematisation of time, nor a sentimental reaction of the human soul to the imminent passing of time, but it is always concrete. It is firstly concrete with its choice of items of "yesterday's world" for meaningful connotations, but also with the message that it conveys with the gesture of seeming abandonment of the present. This brings nostalgia to the field of strained turmoil of ideological discourses and in it, it is never neutral nor is it devoid of ideological motivation. Slavenka Drakulić will assess the seeming de-tabooed topics in history and culture of the Yugoslav society in her essay "Cultural Yugonostalgia as the New Cool", not as a sign of emancipation from the burdening ideologised or falsified interpretation of all aspects of the Yugoslav society and everyday rhetoric of "yesterday's" nationalism, but as a moment of entry of the new ideology as a constructor of the ruling discourse: consumerism.

Certainly, the popularity of nostalgia strategies still needs to be read in a wider context, in addition to specifically detected ideological motivation and targets, and Svetlana Boym will say that nostalgia is "a rebellion against the modern idea of time, time as history and as progress" (p. XV), "a manifestation of collateral effects of the progress technology" (p. 10) in terms of traumatising the individual with the dynamic that actually makes a difference with a single constant. In this context Branko Malić (2014) will, in his essay "To Live and Die At the Last Time" analyse nostalgia as the only remaining time we have due to the crumbling of all possible connections, even with those closest to us, as a result of grinding everyday life. Nostalgia is, he points out, a way of feeling that life was once lived, which becomes a particularly understandable strategy in the transitional climate of these areas.

In this region, nostalgia is far more complex and far more conditioned by triviality: "things in post-socialism are very specific because the societies have been through a very disruptive process of different transitions (...), reckless revisiting of closer history, new exclusivist ideologies, planned amnesia- all of this not only causes an identity crisis with humans, but also serious breakdowns in their narratives" (Velikonja, p.30)

However, rejecting a demand for recognition of Yugoslavs as a minority testifies that such a desire for rehabilitation in the identity narrative, out of complex ideological, cultural and psychological reasons, needs and motivations can be tolerated in the field of culture, but it cannot be politically verified into a subject that would in such a way assume a distressing status, although realistically it would not represent a relevant political force. The underlying reasons for such (in)visible prevention as a manifestation of Freudian narcissism of small differences or the fear of small (Appadurai), as well as contact with the zone of incomplete Other (Luketić), to summarise the discussion, we would reach the key fact that Paul Connerton notes, that "social memory control largely determines the hierarchy of power" (p. 5) since "power relations determine which sphere will stand out in the construction of (Petrović, 2006, p. 215), and "to add unto does not mean to count in, but to distort the budget of power and knowledge" (Bhabha, p. 182).

\section{References}

Appadurai, A. (2008). Strah od malih brojeva. Beograd: XX vek.

Baković, I. (2008). (Jugo)nostalgija kroz naočale popularne kulture. Filološke studije, 2. Retrieved from http://philologicalstudies.org/dokumenti/2008/vol2/2/1.pdf.

Bauman, Z. (2009). Identitet. Zagreb: Pelago.

Bhabha, H. (2002). Diseminacija: vrijeme, pripovijest i margine moderne nacije. In V. Biti (Ed), Politika i etika pripovijedanja (pp. 157-190). Zagreb: Hrvatska sveučilišna naklada.

Bošković, I. (2013). Nostalgija kao obilježje Tribusonova autobiografizma. Croatica, 57, 131-151.

Boym, S. (2001). The Future of Nostalgia. New York: Basic Books.

Buden, B. (2013). Uvod u prošlost. Novi Sad: Centar za nove medije_kuda.org.

Castells, M. (2002). Moć identiteta. Zagreb: Golden Marketing.

Connerton, P. (2004). Kako se društva sjećaju. Zagreb: Antibarbarus.

Dérens, J. A. (2013). Politika popisa stanovništva na Balkanu. Le Monde diplomatique - Croatian edition, 8, 14-15. 
Drakulić, S. (2010). Kulturna jugonostalgija kao novi cool. T-portal. Retrieved from http://www.tportal.hr/kultura/kulturmiks/61462/Kulturna-jugonostalgija-kao-novi-em-cool-em.html.

Drakulić, S. (1997). Kako smo preživjeli. Split: Feral Tribune.

Erdei, I. (2012). Čekajući lkeu - potrošačka kultura u postsocijalizmu i pre njega. Beograd: Srpski genealoški centar. Jameson, F. (2005). Archaeologies of the Future. London-New York: Verso.

Jameson, F. (1991). Postmodernism, Or the Cultural Logic of Late Capitalism. Durham: Duke University Press.

Hutcheon, L. (1998). Irony, Nostalgia and the Postmodern. UTEL. Retrieved from http://www.library.utoronto.ca/utel/criticism/hutchinp.html.

Kalanj, R. (2008). Modernizacija i identitet. Zagreb: Politička kultura.

Kaufmann, J. C. (2006). Iznalaženje sebe. Zagreb: Antibarbarus.

Lozica, I. (2007). O karnevalu: diverzija, kohezija, opsceno i mitsko. Dani hvarskog kazališta, 33(1), 190-208.

Luketić, K. (2013). Balkan: od geografije do fantazije. Zagreb: Algoritam.

Majstorović, D. (2013). Diskursi periferije. Beograd: XX vek.

Malić, B. (2014). Živjeti i umrijeti u pretposljednja vremena. Zarez, 371, 8-9.

Mirković, I. (2004). Sretno dijete. Zagreb, Fraktura.

Petrović, D. (2006). Anatomija identiteta - Teorijsko problematiziranje identiteta. Etnološka istraživanja, 11, 209-233.

Petrović, T. (2011). Što će nama vojničke priče? Sećanje na JNA na prostorima bivše Jugoslavije. I. Prica \& T. Škokić (Eds.), Horror-Porno-Ennui Kulturne prakse postsocijalizma (pp. 413-437). Zagreb: Institut za etnologiju i folkloristiku.

Roth, K. (2012). Od socijalizma do europske unije. Beograd: XX vek.

Škopljanac, L. (2014). Književnost kao prisjećanje. Zagreb: Naklada Ljevak.

Tajder, A. (2013). Titoland. Zagreb: VBZ.

Tomić, A. (2003). Ništa nas ne smije iznenaditi. Zagreb: Fraktura.

Tribuson, G. (2002). Ne dao Bog većeg zla. Zagreb: Mozaik knjiga.

Ugrešić, D. (2002). Kultura laži. Zagreb-Beograd: Konzor-Samizdat B92.

Velikonja, M. (2010). Titostalgija. Beograd: XX vek. 